\title{
UPAYA PENINGKATAN AKTIVITAS DAN HASIL BELAJAR PESERTA DIDIK DI SMPN 3 BANGUNTAPAN MELALUI MODEL PEMBELAJARAN PROBLEM BASED LEARNING
}

\author{
SURYAWATI MUNAWAROH \\ SMP Negeri 3 Banguntapan, Bantul, Yogyakarta \\ suryamuna68@gmail.com
}

\begin{abstract}
ABSTRAK
Upaya peningkatan aktivitas dan hasil belajar IPS di kelas IX C SMP Negeri 3 Banguntapan ditempuh dengan cara melakukan Penelitian Tindakan Kelas yang terdiri dari 2 siklus. Ada empat langkah dalam setiap siklus yaitu Planning, Acting, Observing, dan Reflekting. Tehnik pengambilan data menggunakan studi pustaka, observasi dan dokumentasi. Data aktivitas peserta didik diperoleh melalui lembar observasi dan data hasil belajar diperoleh melalui tes. Tehnik analisa data menggunakan teknik deskriptif kuantatif. Indikator keberhasilan jika 75\% peserta didik telah menunjukkan aktivitas dan memperoleh nilai $\leq 75$ dari hasil penilaian harian. Hasil penelitian menunjukkan bahwa melalui model pembelajaran Problem Based Learning. (1) Penerapan model pembelajaran Problem Based Learning dapat meningkatkan hasil belajar IPS. Hal ini dibuktikan dengan hasil ketuntasan belajar IPS pada pra siklus sebesar 36,67\%, dan meningkat pada siklus 1 sebesar 53,25\%, kemudian pada siklus 2 meningkat menjadi 93\%. Pada siklus 2 ketuntasan hasil belajar belajar IPS peserta didik sudah mencapai indikator keberhasilan yang telah ditentukan yaitu KKM $\geq 75$. Dengan demikian model Pembelajaran Problem Based Learning dapat digunakan untuk meningkatkan hasil belajar IPS peserta didik. (2) Penerapan dapat meningkatkan aktivitas belajar IPS dari $68,47 \%$ di siklus 1 dan siklus 2 meningkat menjadi 78,91\%. (2) Penerapan model pembelajaran Problem Based Learning dapat meningkatkan hasil belajar dari 53,25\% di siklus 1 dan siklus 2 menjadi 93\% peserta didik yang mencapai KKM yang ditentukan sebesar yaitu sebesar $\geq 75 \%$.
\end{abstract}

Kata kunci: aktivitas belajar, hasil belajar, problem based learning, IPS

\section{PENDAHULUAN}

Pembelajaran IPS bertujuan membentuk peserta didik memiliki kemampuan untuk berpikir logis dan kritis guna menciptakan kondisi kehidupan yang lebih baik, mempunyai kemandirian, dan mampu mengatasi masalah-masalah sosial yang terjadi. Untuk mewujudkan tujuan pembelajaran IPS di atas, dibutuhkan proses pembelajaran yang mampu menumbuhkan aktivitas peserta didik dalam memahami konsep dan prinsip yang berkaitan dengan pola persebaran keruangan, interaksi sosial, pemenuhan kebutuhan, dan perkembangan masyarakat serta kemampuan membuat keputusan guna memecahkan masalah-masalah sosial yang terjadi di masyarakat.

Pembelajaran IPS di kelas IX C ditemukan beberapa hal yang menunjukkan pembelajaran IPS belum sesuai dengan yang diharapkan karena belum mampu 
menumbuhkan aktivitas belajar peserta didik. Salah satu indikator peserta didik dikatakan aktif dalam proses pembelajaran jika ada keterlibatan aspek intektual, emosional ataupun fisik peserta didik dalam proses pembelajaran. Kurikulum 2013 merupakan kurikulum yang berbasis kompetensi yang menekankan pembelajaran yang berbasis aktivitas dengan tujuan memfasilitasi peserta didik memperoleh penilaian sikap, pengetahuan, dan ketrampilan, baik selama proses maupun pada akhir semester. Penilaian pengetahuan pembelajaran IPS mengacu pada ketuntasan Kompetensi Dasar (KD). Ketuntasan penilaiannya dilakukan setelah tercapai satu bab atau satu KD. Peserta didik dinyatakan berhasil mencapai tujuan pembelajaran IPS apabila telah mencapai kriteria ketuntasan minimal (KKM) yang telah ditetapkan sekolah yaitu sebesar 75. Peserta didik dinyatakan tuntas dan tidak mengikuti remidi apabila perolehan nilai ulangan harian $\geq 75$. Nilai ulangan yang diperoleh peserta didik pada mata pelajaran IPS di kelas IX C diperoleh nilai 75 atau di atas 75 berjumlah 13 orang dari 32 atau 36,67 \%, sedangkan peserta didik yang memperoleh nilai di bawah 75 (tidak tuntas) berjumlah 19 orang dari 32 peserta didik atau 63,33\%.

Untuk mengatasi permasalahan pembelajaran di atas adalah dengan menggunakan model pembelajaran Problem Based Learning (PBL). Model pembelajaran Problem Based Learning dapat diartikan sebagai rangkaian aktivitas pembelajaran yang menekankan pada proses penyelesaian masalah yang dihadapi secara ilmiah melalui serangkaian aktivitas pembelajaran yang harus dilakukan peserta didik, jadi peserta didik bukan sekedar mendengarkan, mencatat, kemudian menghafal materi pelajaran, akan tetapi melalui Problem Based Learning peserta didik aktif berpikir, berkomunikasi, mencari, mengolah data dan akhirnya membuat kesimpulan dan dihadapkan pada suatu permasalahan tertentu yang nyata terjadi di masyarakat, kemudian dalam diskusi kelompok peserta didik menyelesaikan permasalahan tersebut dengan bekal pengetahuan yang dimiliki. Berdasarkan latar belakang dan identifikasi masalah di atas, maka permasalahan yang dapat diungkap melalui penelitian ini dapat dinyatakan dalam rumusan masalah sebagai berikut: 1) Bagaimana model pembelajaran Problem Based Learning dapat meningkatkan hasil belajar mata pelajaran IPS pada peserta didik kelas IX C SMPN 3 Banguntapan melalui tahun pelajaran 2019/2020. 2) Bagaimana peningkatan aktivitas belajar pada mata pelajaran IPS peserta didik kelas IX C SMPN 3 Banguntapan melalui model pembelajaran Problem Based Learning tahun pelajaran 2019/2020. Hamalik (2015:30) menjelaskan, hasil belajar sebagai bukti bahwa seseorang telah belajar ialah terjadinya perubahan tingkah laku pada orang tersebut, misalnya dari tidak tahu menjadi tahu, dan dari tidak mengerti menjadi mengerti. Tingkah laku manusia terdiri dari sejumlah aspek. Hasil belajar akan tampak pada setiap perubahan pada aspek-aspek tersebut. Aspek-aspek itu adalah: pengetahuan, pengertian, kebiasaan, keterampilan, apresiasi, emosional, hubungan sosial, jasmani, etis dan sikap. Sudjana (2010:61), aktivitas peserta didik dalam proses belajar mengajar, antara lain: (1) turut serta dalam melaksanakan tugas belajarnya; (2) terlibat dalam pemecahan masalah; (3) bertanya kepada peserta didik lain atau bertanya guru apabila tidak memahami persoalan yang dihadapinya; (4) berusaha mencari berbagai informasi yang diperlukan untuk pemecahan masalah; (5) melaksanakan diskusi kelompok sesuai dengan petunjuk guru; (6) menilai kemampuan dirinya dan hasil-hasil yang diperolehnya; (7) melatih diri dalam memecahkan soal atau 
masalah yang sejenis; (8) kesempatan menggunakan atau menerapkan apa yang telah diperolehnya dalam menyelesaikan tugas atau persoalan yang dihadapinya.

Rusman (2014:77) model pembelajaran Problem Based Learning adalah sebuah model pembelajaran yang melibatkan peserta didik untuk berusaha memecahkan masalah dengan melalui beberapa tahapan ilmiah sehingga peserta didik diharapkan mampu mempelajari pengetahuan yang berkaitan dengan masalah tersebut dan sekaligus peserta didik diharapkan akan memiliki ketrampilan dalam memecahkan masalah. Arends dalam Ngalimun (2016:124) merinci langkah-langkah pelaksanaan pembelajaran Problem Based Learning dalam lima fase sintak Problem Based Learning. Berikut adalah tabel sintak dari pembelajaran Problem Based Learning: 1) Mengorientasikan peserta didik pada masalah, 2) Mengorganisasi peserta didik untuk belajar, 3) Membimbing peserta didik dalam diskusi kelompok, 4) Mengembangkan dan menyajikan hasil diskusi pemecahan masalah, 5) Menganalisis dan mengevaluasi proses pemecahan masalah.

Hipotesis dalam penelitian ini adalah; 1)Melalui model pembelajaran Problem Based Learning dapat meningkatkan aktivitas belajar peserta didik pada mata pelajaran IPS kelas IX C SMP Negeri 3 Banguntapan tahun pelajaran 2019/2020Melalui model pembelajaran Problem Based Learning dapat meningkatkan hasil belajar peserta didik pada mata pelajaran IPS kelas IX C SMP Negeri 3 Banguntapan tahun pelajaran 2019/2020.

\section{METODE PENELITIAN}

Penelitian ini dilakukan di kelas IX C SMP N 3 Banguntapan dengan Subjek Penelitian Peserta didik kelas IX C Semester 1 tahun pelajaran 2019/2020 SMP N 3 Banguntapan dengan jumlah peserta didik 32 yang terdiri dari 16 putra dan 16 putri, dengan objek penelitian peningkatkan aktivitas, kemandirian, dan hasil belajar Peserta Didik Kelas IX C Semester 1 SMP N 3 Banguntapan Melalui Model Pembelajaran Problem Based Learning Tahun Pelajaran 2019 / 2020. Analisis Data Kualitatif. Teknik analisis data yang digunakan; 1) Teknik Analisis Data Kuantitatif yakni dinyatakan dalam bentuk persentase (\%) yaitu jumlah peserta didik yang telah menacapai batas ketuntasan minimal dibagi dengan jumlah peserta didik, dengan ketentuan mencapai KKM yang telah ditentukan yaitu 75. 2) Teknik analisis data kualitatif dilakukan secara deskriptif analitis kualitatif, yaitu mendeskripsikan pelaksanaan analisis data yang dilakukan yaitu sebelum melaksanakan tindakan, proses pelaksanaan tindakan dan selesai di lapangan. Metode yang dipakai dalam penelitian ini adalah metode Penelitian Tindakan kelas dengan dua siklus. Arikunto, 2008 menyatakan bahwa dalam setiap siklus penelitian tindakan kelas meliputi 4 tahap yaitu: (1) perencanaan (Planning), (2) pelaksanaan tindakan (Acting), (3) Pengamatan (Observing) (4) Refleksi ( Reflecting).

\section{HASIL PENELITIAN DAN PEMBAHASAN}

\section{A. Hasil Penelitian}

Pelaksanaan pengamatan pra siklus dilakukan pada akhir bulan Agustus. Halhal yang diamati adalah kegiatan pembelajaran IPS di antaranya aktivitas belajar 
peserta didik kelas IX C. Hasil pengamatan pra siklus diketemukan beberapa permasalahan berkaitan dengan proses pembelajaran di kelas. Peserta didik masih pasif, aktivitas fisik, kognitif, dan emosional masih sangat kurang. Guru saat menyampaikan meteri masih dominan ceramah sambil sesekali melakukan tanya jawab dengan peserta didik, tetapi keaktifan peserta didik belum terlihat. Selama dua jam pelajaran aktivitas peserta didik dominan duduk mendengarkan. Hal ini terjadi dikarenakan model pembelajaran yang dirancang guru kurang memberi ruang bagi peserta didik untuk aktif menggali kognisi, emosional, dan fisik mereka. Peneliti mengambil data hasil belajar peserta didik berasal dari dokumen nilai ulangan harian KD 3.1 mengenai materi perubahan keruangan dan interaksi antar ruang negara-negara Asia dan benua lainnya. Dari dokumen diperoleh informasi ulangan harian diikuti seluruh peserta didik sebanyak 32 (tiga puluh) peserta didik. Adapun nilai hasil ulangan diperoleh informasi bahwa rata-rata ulangan harian mencapai 69,47. Rata-rata perolehan masih di bawah kriteria ketuntasan yang ditetapkan yaitu $\geq 75$. Untuk memperjelas data tersebut di atas, peneliti sajikan persentase ketuntasan hasil belajar pada pra siklus seperti pada tabel berikut:

Tabel 1. Tingkat Ketuntasan Hasil Belajar IPS Pra Siklus

\begin{tabular}{ccc}
\hline Nilai & Jumlah Siswa & \% Ketuntasasan \\
\hline$<75$ & 19 & $63,33 \%$ \\
\hline$\geq 75$ & 13 & $36,67 \%$ \\
\hline & 32 & $100 \%$ \\
\hline Rata-rata kelas & 69.47 &
\end{tabular}

\section{Siklus 1}

Siklus 1 dari hasil pengamatan aktivitas belajar siswa diperoleh data nilai aktivitas belajar siswa pada pertemuan 1 mencapai 64,57\%, sedangkan persentase aktivitas belajar siswa pada pertemuan 2 meningkat menjadi 72,36\%. Sehingga ratarata persentase aktivitas belajar siswa pada siklus 1 adalah $68,47 \%$. Persentase aktivitas belajar siswa pada siklus I dalam mengikuti kegiatan pembelajaran IPS yang menerapkan metode Problem Based Learning tersebut belum mencapai indikator keberhasilan yang ditetapkan yaitu $\geq 70 \%$. Data persentase aktivitas belajar siswa pada siklus 1 dapat dilihat pada tabel berikut ini:

Tabel 2. Persentase Aktivitas Belajar Siswa pada Siklus 1

\begin{tabular}{llccc}
\hline No $\quad$ Indikator Aktivitas Belajar & $\begin{array}{c}\text { Pertemuan } \\
\mathbf{1}\end{array}$ & $\begin{array}{c}\text { Pertemuan } \\
\mathbf{2}\end{array}$ & $\begin{array}{c}\text { Rata-rata } \\
\text { Siklus 1 }\end{array}$ \\
\hline $\begin{array}{l}\text { Kemampuan } \\
\begin{array}{l}\text { memperhatikan penjelasan guru } \\
\text { ataupun peserta didik lain saat } \\
\text { diskusi }\end{array}\end{array}$ & $75,00 \%$ & $79,16 \%$ & $77,08 \%$ \\
\hline
\end{tabular}




\begin{tabular}{llllc}
\hline 2 & $\begin{array}{l}\text { Partisipasi peserta didik dalam } \\
\text { diskusi }\end{array}$ & 67,67 & 78,33 & $73 \%$ \\
\hline $3 \begin{array}{l}\text { Keaktifan bertanya, menjawab, } \\
\text { membuat catatan saat pembelajaran }\end{array}$ & $43,75 \%$ & $56,25 \%$ & $50,00 \%$ \\
\hline 4 Komitmen mengerjakan tugas & $54,14 \%$ & $63,54 \%$ & $58,85 \%$ \\
\hline $\begin{array}{l}\text { Berusaha mencari berbagai } \\
\text { informasi yang diperlukan untuk } \\
\text { pemecahan masalah. }\end{array}$ & $77,00 \%$ & $80,02 \%$ & $78,51 \%$ \\
\hline $\begin{array}{l}\text { Kemampuan mempresentasikan } \\
\text { hasil diskusi }\end{array}$ & $37,50 \%$ & $55,20 \%$ & $46,35 \%$ \\
\hline Nilai Rata-Rata Persentase Aktivitas & $64,57 \%$ & $72,36 \%$ & $68,47 \%$ \\
\hline
\end{tabular}

Hasil belajar peserta didik dalam siklus 1 diperoleh dari nilai ulangan harian, berupa penyelesaian soal-soal tentang materi perubahan sosial budaya yang dilaksanakan di akhir siklus 1, setelah kegiatan pembelajaran menggunakan model pembelajaran Problem Based Learning. Hasil belajar peserta didik kelas IX C pada mata pelajaran IPS pada siklus 1 sudah ada peningkatan hasil belajar, tetapi masih belum sesuai yang diharapkan. Hasil belajar siklus 1 untuk materi bentuk-bentuk perubahan sosial budaya menunjukkan nilai rata-rata kelas sebesar 72,1 dapat dikatakan nilai rata-rata kelas belum melampaui batas KKM yang ditentukan yaitu 275, sehingga masih perlu diadakan perbaikan pada tindakan berikutnya. Tingkat ketuntasan hasil belajar peserta didik pada siklus 1 disajikan dalam tabel di bawah ini:

Tabel 3. Ketuntasan Hasil Belajar IPS Peserta Didik dengan Menggunakan Model Pembelajaran Problem Based Learning.

\begin{tabular}{cccc}
\hline No & Nilai KKM & $\begin{array}{c}\text { Jumlah Peserta } \\
\text { Didik }\end{array}$ & $\begin{array}{c}\text { Persentase } \\
\text { Ketuntasan }\end{array}$ \\
\hline 1 & $<$ KKM atau <75 & 14 & $43,8 \%$ \\
\hline 2 & $\geq$ KKM atau $\geq 75$ & 18 & $56,3 \%$ \\
\hline & & 32 & $100 \%$ \\
\hline
\end{tabular}

Berdasar pada tabel ketuntasan hasil belajar pada siklus 1 di atas peserta didik yang mencapai ketuntasan sebanyak 18 peserta didik atau sebesar 56,3\%, sementara peserta didik yang belum mencapai ketuntasan minimal sebanyak 14 peserta didik atau sebesar 43.8\%, sehingga dilihat dari persentase ketuntasan minimal pada siklus 1 dapat dikatakan belum mencapai batas ketuntasan klasikal yaitu dari $\geq 75 \%$. 


\section{Siklus 2}

Pelaksanaan siklus 2 dilakukan dalam 2 kali tatap muka, pertemuan pertama dilakukan pada hari Selasa pada tanggal 22 Oktober 2019 dan pertemuan kedua dilakukan pada hari Kamis pada tanggal 24 Oktober 2019 dengan KD 3.2, dengan materi mengenai "menganalisis perubahan kehidupan sosial budaya bangsa Indonesia dalam menghadapi arus globalisasi untuk memperkokoh kehidupan kebangsaan, dengan sub tema mengenai globalisasi." Setelah dilakukan tatap muka 2 kali pertemuan, untuk mengukur hasil belajar peserta didik dilakukan tes formatif yang diadakan pada akhir siklus. Nilai aktivitas belajar siswa pada siklus 2 dapat disimpulkan bahwa aktivitas belajar siswa telah meningkat dari siklus sebelumnya dan telah mencapai indikator keberhasilan yang telah ditentukan. Pada pertemuan 3 persentase aktivitas belajar siswa mencapai 76,56\%. Sedangkan pada pertemuan 4 persentase aktivitas belajar siswa meningkat menjadi $81,42 \%$. Sehingga persentase aktivitas belajar siswa pada siklus 2 adalah 78,99\%. Persentase keterlibatan siswa dalam kegiatan pembelajaran yang menerapkan metode Problem Based Learning tersebut sudah mencapai indikator keberhasilan yang ditetapkan yaitu $\geq 75 \%$.

Hasil pengamatan dari aktivitas peserta didik dalam pembelajaran IPS setelah menggunakan model pembelajaran problem based learniang sebagai berikut:

Tabel 4. Hasil Observasi Aktivitas Belajar IPS Peserta Didik Setelah menggunakan Model Problem Based Learning Siklus 2

\begin{tabular}{|c|c|c|c|c|}
\hline No & Aktivitas yang Diamati & Pert 1 & Pert 2 & $\begin{array}{l}\text { Rata-rata } \\
\text { siklus } 2\end{array}$ \\
\hline 1 & $\begin{array}{l}\text { Kemampuan } \\
\text { memperhatikan penjelasan guru } \\
\text { ataupun peserta didik lain saat } \\
\text { diskusi }\end{array}$ & $79,16 \%$ & $79,16 \%$ & $79,16 \%$ \\
\hline 2 & $\begin{array}{l}\text { Partisipasi peserta didik dalam } \\
\text { diskusi }\end{array}$ & $96,87 \%$ & $96,87 \%$ & $96,87 \%$ \\
\hline 3 & $\begin{array}{l}\text { Keaktifan bertanya, menjawab, } \\
\text { membuat catatan } \\
\text { pembelajaran }\end{array}$ & $68,75 \%$ & $80,20 \%$ & $74,48 \%$ \\
\hline 4 & Komitmen mengerjakan tugas & $61,58 \%$ & $70,83 \%$ & $66,21 \%$ \\
\hline 5 & $\begin{array}{l}\text { Berusaha mencari berbagai } \\
\text { informasi yang diperlukan untuk } \\
\text { pemecahan masalah. }\end{array}$ & $79,16 \%$ & $84,37 \%$ & $81,77 \%$ \\
\hline 6 & $\begin{array}{l}\text { Kemampuan mempresentasikan } \\
\text { hasil diskusi }\end{array}$ & $70,83 \%$ & $79,16 \%$ & $75,00 \%$ \\
\hline & Rata-rata & $76,06 \%$ & $81,77 \%$ & $78,91 \%$ \\
\hline
\end{tabular}

Berdasarkan aspek-aspek aktivitas yang diamati dalam tabel di atas, dapat dikatakan bahwa aktivitas belajar peserta didik dalam pembelajaran IPS dengan model 
pembelajaran problem based learning sudah baik. Sebanyak 32 peserta didik pada siklus 2 sudah menunjukkan aktivitas belajajar yang baik atau capaian peningkatan aktivitas belajar peserta didik sebesar 78,91\%. Ini berarti tingkat aktivitas belajar peserta didik sudah dikatakan baik dan mencapai $\geq 75 \%$. Kelima aspek aktivitas belajar mengalami. Pada siklus 2 peserta didik sudah bisa mengikuti proses pembelajaran dengan baik, hal ini terlihat dari semangat dan keaktifan peserta didik pada saat proses pembelajaran. Hasil Belajar peserta didik dalam siklus 2 diperoleh dari nilai ulangan harian berupa penyelesaian soal-soal tentang materi globalisasi yang dilaksanakan pada akhir siklus 2, setelah kegiatan pembelajaran menggunakan model pembelajaran Problem Based Learning.

Hasil belajar siklus 2 sudah mencapai kriteria ketuntasan minimum yaitu mencapai 93\%, dengan rata-rata nilai 80,14, dengan nilai tertinggi 90 dan nilai terendah 55. Hasil perolehan hasil belajar tersebut sudah melampui batas ketuntasan minimal yaitu $\geq 75 \%$, sehingga siklus 2 dapat dihentikan. Berdasar pada ketuntasan hasil belajar pada siklus 2 di atas dapat dibuat tabel persentase ketuntasan belajar sebagai berikut:

Tabel 5. Persentase Ketuntasan Hasil Belajar Peserta Didik Menggunakan Model Pembelajaran Problem Based Learning.

\begin{tabular}{lccc}
\hline No & Nilai KKM & Jumlah Peserta Didik & $\begin{array}{c}\text { Persentase } \\
\text { Ketuntasan }\end{array}$ \\
\hline 1 & $<$ KKM atau $<75$ & 3 & $7 \%$ \\
\hline 2 & $\geq$ KKM atau $\geq 75$ & 29 & $93 \%$ \\
\hline & & 32 & $100 \%$ \\
\hline
\end{tabular}

\section{B. Pembahasan Hasil Penelitian}

1. Peningkatan Aktivitas Belajar Peserta Didik Kelas IX C SMPN 3 Banguntapan

Setelah Menggunakan Model Pembelajaran Problem Based Learning aktivitas belajar peserta didik mengalami peningkatan. Tahap pra siklus masih menunjukkan kategori kurang karena hanya $46 \%$ peserta didik yang masuk kategori baik. Persentase ini terus meningkat di siklus 1 dan siklus 2. Hasil observasi model pembelajaran Problem Based Learning dapat meningkatkan aktivitas belajar peserta didik kelas IX C SMPN 3 Banguntapan. Dengan model Problem Based Learning aktivitas kognitif peserta didik dilatih untuk berpikir kritis, memecahkan masalah, dan mampu mengambil keputusan dengan tepat. Aktivitas fisik dan emosional peserta didik terlihat saat proses diskusi, peserta didik terlihat mulai bersemangat memecahkan masalah dalam kelompok diskusi.

Respon baik terhadap penerapan model pembelajaran Problem Based Learning mulai terlihat pada siklus 1. Siklus 1 aktivitas belajar peserta didik mencapai $68,47 \%$ terdapat peningkatan sebesar 9,33\% dibanding saat pembelajaran belum menggunakan model Problem Based Learning. Siklus 2 peserta didik mulai terbiasa dengan model pembelajaran Problem Based Learning, hal ini terlihat dari meningkatnya aktivitas belajar peserta didik sebesar 13,53\%, Pada siklus 2 ini aktivitas belajar mencapai 78,91\%. 
Peningkatan ini merata untuk seluruh aspek aktivitas belajar yang diamati. Berikut disajikan tabel 16 yang menggambarkan peningkatan aktivitas belajar peserta didik:

Tabel 6. Peningkatan Aktivitas Belajar IPS Siklus 1, dan Siklus 2

\begin{tabular}{clcc}
\hline No & Variabel Penilaian & \multicolumn{1}{c}{ Siklus 1 } & Siklus 2 \\
\hline 1 & $\begin{array}{l}\text { Kemampuan mendengar, } \\
\text { memperhatikan penjelasan guru } \\
\text { ataupun peserta didik lain saat } \\
\text { diskusi }\end{array}$ & $77,08 \%$ & $79,16 \%$ \\
\hline 2 & $\begin{array}{l}\text { Partisipasi peserta didik dalam } \\
\text { diskusi }\end{array}$ & $73 \%$ & $96,87 \%$ \\
\hline 3 & $\begin{array}{l}\text { Keaktifan bertanya, menjawab, } \\
\text { membuat catatan saat } \\
\text { pembelajaran 50,00\% }\end{array}$ & $74,48 \%$ \\
\hline 4 & $\begin{array}{l}\text { Komitmen mengerjakan tugas } \\
\text { Berusaha mencari berbagai } \\
\text { informasi yang diperlukan untuk } \\
\text { pemecahan masalah. }\end{array}$ & $78,51 \%$ & $81,77 \%$ \\
\hline 6 & $\begin{array}{l}\text { Kemampuan mempresentasikan } \\
\text { hasil diskusi }\end{array}$ & $46,35 \%$ & $75,00 \%$ \\
\hline & $68,47 \%$ & $78,91 \%$ \\
\hline
\end{tabular}

Tabel di atas menunjukkan peningkatan dari aktivitas belajar peserta didik melalui penerapan model pembelajaran Problem Based Learning. Pada pra siklus dimana belum diterapkan model pembelajaran Problem Based Learning aktivitas peserta didik yang terlihat hanya sebesar 52\%. Siklus 1 mulai terlihat aspek aktivitas belajar mengalami peningkatan tetapi semua aspek masih di bawah kriteria yang ditentukan dengan rata-rata 68,47\%. Siklus 2 semua aspek aktivitas belajar yang diamati menunjukkan peningkatan dan capaian di atas kriteria yang ditetapkan, dengan rata-rata sebesar 78,91\%. Peningkatan ini sudah mancapai batas ketentuan yang ditetapkan $75 \%$. Penelitian ini diakhiri pada siklus 2 karena sudah mencapai keberhasilan yang ditentukan. Berikut jika disajikan dalam diagram:

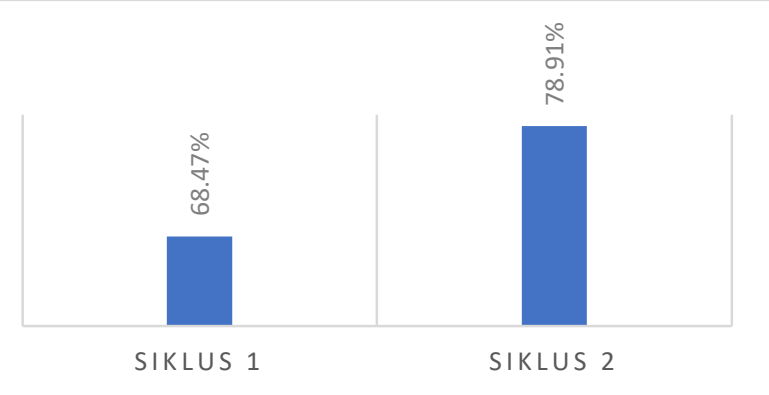

Gambar 1. Hasil aktivitas belajar siklus 1 dan siklus 2 
2. Peningkatan Hasil Belajar IPS Peserta Didik Kelas IX C SMPN 3 Banguntapan Setelah menggunakan Model Pembelajaran Problem Based Learning, hasil belajar peserta didik pada mata pelajaran IPS mengalami peningkatan. Tahap pra siklus ketuntasan hasil belajar baru mencapai 36,67\% atau sebanyak 11 peserta didik dari 32 peserta didik. Angka ini meningkat setelah diterapkan model pembelajaran Problem Based Learning, Peningkatan ini terlihat pada siklus 1 yaitu meningkat sebesar $23 \%$ menjadi 53,25\% . Walaupun pengalami peningkatan, tetapi hasil belajar pada siklus 1 belum sesuai yang diharapkan, karena masih di bawah 75\%. Pada siklus 2 mengalami peningkatan cukup baik yaitu ketuntasan mencapai mencapai 93\%. Hal ini menunjukkan bahwa penggunaan model pembelajaran Problem Based Learning, dapat menambah pemahaman dari materi pelajaran yang disampaikan. Siklus 2 Peserta didik yang belum mencapai ketuntasan tinggal 2 peserta didik atau sebesar $7 \%$. Peningkatan hasil ketuntasan belajar peserta didik pada pra siklus, siklus 1, dan siklus 2

Tingkat ketuntasan hasil belajar peserta didik pada siklus 1 disajikan dalam tabel di bawah ini:

Tabel 7

Ketuntasan Hasil Belajar IPS Peserta Didik denganMenggunakan Model Pembelajaran Problem Based Learning.

\begin{tabular}{lccc}
\hline No & \multirow{2}{*}{ Nilai KKM } & $\begin{array}{c}\text { Jumlah Peserta } \\
\text { Didik }\end{array}$ & $\begin{array}{c}\text { Persentase } \\
\text { Ketuntasan }\end{array}$ \\
\hline 1 & $<$ KKM atau $<75$ & 14 & $43,8 \%$ \\
\hline 2 & $\geq$ KKM atau $\geq 75$ & 18 & $56,3 \%$ \\
\hline & & 32 & $100 \%$ \\
\hline
\end{tabular}

Berdasar pada tabel ketuntasan hasil belajar pada siklus 1 di atas peserta didik yang mencapai ketuntasan sebanyak 18 peserta didik atau sebesar 56,3\%, sementara peserta didik yang belum mencapai ketuntasan minimal sebanyak 14 peserta didik atau sebesar $43.8 \%$, sehingga dilihat dari persentase ketuntasan minimal pada siklus 1 dapat dikatakan belum mencapai batas ketuntasan klasikal yaitu dari $\geq 75 \%$.

Setelah menggunakan Model Pembelajaran Problem Based Learning, hasil belajar peserta didik pada mata pelajaran IPS mengalami peningkatan. Tahap pra siklus ketuntasan hasil belajar baru mencapai 36,67\% atau sebanyak 11 peserta didik dari 32 peserta didik. Angka ini meningkat setelah diterapkan model pembelajaran Problem Based Learning, Peningkatan ini terlihat pada siklus 1 yaitu meningkat sebesar $23 \%$ menjadi 53,25\%. Hasil belajar pada siklus 1 belum sesuai yang diharapkan, karena masih di bawah 75\%. Pada siklus 2 mengalami peningkatan cukup baik yaitu ketuntasan mencapai mencapai 93\%. Hal ini menunjukkan bahwa penggunaan model pembelajaran Problem Based Learning, dapat menambah pemahaman dari materi pelajaran yang disampaikan. Siklus 2 Peserta didik yang belum mencapai ketuntasan 
tinggal 2 peserta didik atau sebesar 7\%. Peningkatan hasil ketuntasan belajar peserta didik pada pra siklus, siklus 1 , dan siklus 2 disajikan dalam tabel berikut di bawah ini:

Tabel 8

Persentase Ketuntasan Hasil Belajar IPS Peserta Didik Setelah Menggunakan Model Pembelajaran Problem Based Learning.

\begin{tabular}{llccc} 
No & \multicolumn{1}{c}{ Nilai KKM } & Pra Siklus & Siklus 1 & Siklus 2 \\
\hline 1 & $\begin{array}{l}\text { Jumlah Peserta } \\
\text { Didik yang Tuntas }\end{array}$ & 11 & 18 & 29 \\
\hline 2 & $\begin{array}{l}\text { Jumlah peserta } \\
\text { didik keseluruhan }\end{array}$ & 32 & 32 & 32 \\
\hline 3 & $\geq$ KKM atau $\geq 75$ & $36,67 \%$ & $53,25 \%$ & $93 \%$ \\
\hline
\end{tabular}

Untuk memperjelas tabel di atas berikut disajikan grafik yang menggambarkan peningkatan hasil ketuntasan belajar peserta didik:

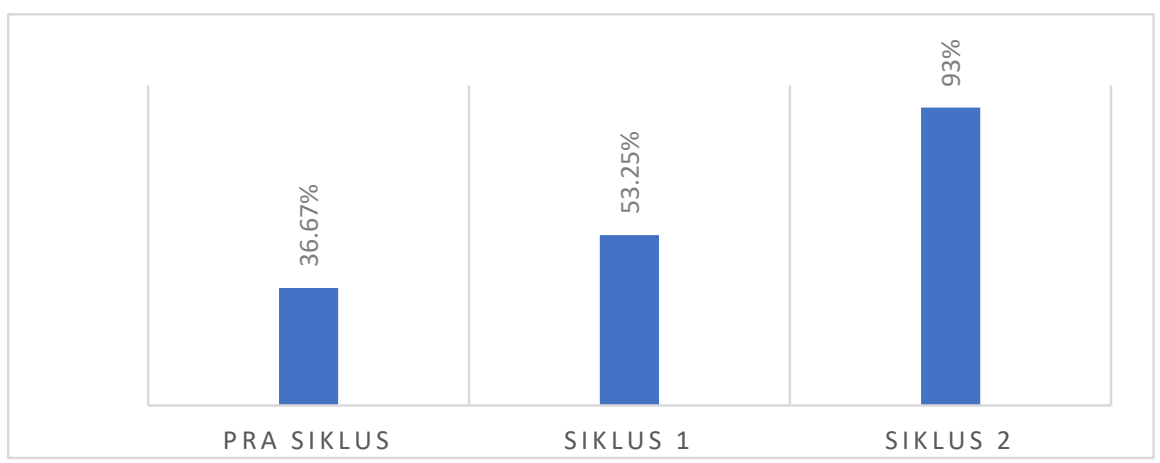

Diagram 2. Hasil belajar siklus 1 dan siklus 2

Berdasarkan tabel dan grafik ketuntasan belajar peserta didik, dari pra siklus sampai dengan siklus 2 terus mengalami peningkatan. Pada pra siklus ketuntasan belajar hanya mencapai 36,67\%, ketuntasan mulai meningkat pada siklus 1 yaitu mencapai 53,25\%. Pada akhir siklus 2 hasil ketuntasan belajar peserta didik telah mencapai 93\%, ini berarti hasil belajar pada siklus 2 sudah di atas KKM yang ditetapkan yaitu sebesar $\geq 75 \%$. Berdasar pada hasil capaian hasil belajar siklus 2 tersebut penelitian ini dihentikan sampai siklus 2 karena hasil belajar sudah mencapai batas ketuntasan minimal yaitu $\geq 75 \%$.

Hasil penelitian ini sesuai dengan penelitian yang dilakukan Tasmin A Yacub (2020). Dalam penelitiannya, Tasmin A Yacub menunjukkan adanya peningkatan kemampuan hasil belajar peserta didik dengan menggunakan model pembelajaran Problem Based Learning dengan prosesntase ketuntasan hasil belajar pada siklus 1 sebesar $74,80 \%$ dan pada siklus 2 sebesar 94,28\%. Penelitian ini dilakukan pada peserta didik kelas IX SMP Negeri 2 Tolitoli tahun pelajaran 2018/2019. 


\section{KESIMPULAN}

Dari hasil penelitian dan pembahasan yang telah dikemukakan sebelumnya, peneliti dapat menyimpulkan bahwa:

1. Penerapan model pembelajaran Problem Based Learning dapat meningkatkan aktivitas belajar IPS. Hal ini dibuktikan dengan aktivitas belajar IPS pada pra siklus sebesar 52\%, dan meningkat pada siklus 1 sebesar 68,47\%, kemudian pada siklus 2 meningkat menjadi 78,91\%. Persentase aktivitas belajar peserta didik mengalami peningkatan sebesar $11 \%$. Dengan demikian model Pembelajaran Problem Based Learning dapat digunakan untuk meningkatkan aktivitas peserta didik dalam pembelajaran IPS.

2. Penerapan model pembelajaran Problem Based Learning dapat meningkatkan hasil belajar IPS. Hal ini dibuktikan dengan hasil ketuntasan belajar IPS pada pra siklus sebesar 36,67\%, dan meningkat pada siklus I sebesar 53,25\%, kemudian pada siklus 2 meningkat menjadi 93\%. Pada siklus 2 ketuntasan hasil belajar belajar IPS peserta didik sudah mencapai indikator keberhasilan yang telah ditentukan yaitu KKM $\geq 75$. Dengan demikian model Pembelajaran Problem Based Learning dapat digunakan untuk meningkatkan hasil belajar IPS peserta didik.

\section{DAFTAR PUSTAKA}

Amir, Taufiq.2009. Inovasi Pendidikan Melalui Problem Based Learning. Jakarta:Prenadamedia Grup

Daryanto. 2013. Pendekatan Pembelajaran Saintifik. Yogyakarta: Gava Media

Miftahul, Huda.2017. Model-Model Pengajaran dan Pembelajaran.Yogyakarta : Pustaka Pelajar

Miswar, Deddy. 2016. Perbedaan Penerapan Model Problem Based Learning Pada Hasil Belajar Geografi. Yogyakarta:Media Akademi

Ngalimun. 2017.Straregi dan Model Pembelajaran. Yogyakarta:Aswaja Pressindo

Oemar, Hamalik. 2001. Proses Belajar Mengajar, Jakarta : Bumi Aksara

Rusman. 2014. Model-Model Pembelajaran. Jakarta:PT Grafindo Perakasa

Rusmono. 2017. Strategi Pembelajaran Dengan Probem Based Learning. Bogor: Ghalia Indonesia

Slameto. 2010. Belajar dan Faktor-faktor yang Mempengaruhinya. Jakarta: Rineka Cipta.

Suharsimi Arikunto. 2008.Penelitian Tindakan Kelas. Jakarta: Bumi Aksara Sudjana, Nana.2010. Cara Belajar Siswa Aktif.Bandung:Sinar Baru

Sudjana, Nana.2010. Penelitian dan Penilaian Pendidikan.Bandung:Sinar Baru Sugiyono.2014. Metode Penelitian Kuantitatif, Kualitatif, dan R\&D.Bandung: Alfa Beta

Tasmin A Yakob. 2020. Model Pembelajaran Problem Based Learning Dalam Peningkatan Hasil Belajar IPS (Studi Penelitian Tindakan Kelas di SMP Negeri 2 Tolitoli) https://ojs.umada.ac.id/index.php/Tolis_Ilmiah/article/view/126 
Undang-Undang Republik Indonesia Nomor 20 Tahun 2003 Tentang Sistem Pendidkan Nasional.

Yonny Acep, dkk. 2010. Menyusun Penelitian Tindakan Kelas. Yogyakarta: Familia.

Yusfy. (2011). Pengertian Aktivitas Belajar. Online. Avalaible at http://id.shvoong.com/social-sciences/education/2241185-pengertian-aktivitasbelajar/. Diakses pada 29 Desember 2013. 